\title{
From Perth to Wellington: a 30-year journey
}

\author{
Kenneth E Warner
}

Health Management and Policy, University of Michigan School of Public Health, Ann Arbor, Michigan, USA

\section{Correspondence to}

Professor Emeritus Kenneth E Warner, Health Management and Policy, University of Michigan School of Public Health, Ann Arbor, Ml 48109, USA; kwarner@umich.edu

Received 19 December 2021 Accepted 21 December 2021

\section{Check for updates}

(c) Author(s) (or their employer(s)) 2022. No commercial re-use. See rights and permissions. Published by BMJ.

To cite: Warner KE.

Tob Control

2022:31:123-124
In 1990, at the 7th World Conference on Smoking and Health in Perth, Western Australia, a group of tobacco control researchers met in an informal meeting to discuss the idea of creating a journal devoted exclusively to tobacco control. I expressed scepticism, unconvinced that there was enough high-quality research to sustain a journal so singularly focused on one health behaviour. Fortunately, the more visionary participants in that meeting prevailed and in March 1992, issue 1 of volume 1 of Tobacco Control was published. My scepticism notwithstanding, Dr Ron Davis, the journal's founding editor-in-chief, asked me to chair the Editorial Advisory Board, a position I have been honoured to fill since the journal's inception.

That my scepticism was unwarranted has been demonstrated a hundred times over, quite literally. Prior to this 30th anniversary issue, by my count the journal has published 154 regular issues, plus 49 supplements and 18 e-supplements. That amounts to 221 issues of all three varieties. With each containing 15 or more independent intellectual contributions, from editorials to original research papers to reviews, that amounts to over 3000 contributions to better understanding the nature of tobacco product use, how it can be reduced, how forces increasing and decreasing tobacco product use affect core health indices including death tolls and life expectancy, how politics, economics, law, social interaction and tobacco industry behaviour affect the trajectory of tobacco product use, and so much more.

All this really matters. Tobacco use remains public health enemy number 1 . Worldwide the vast majority of tobacco-produced disease and death results from cigarette smoking, ${ }^{1}$ although in a few countries, including India and the Sudan, highly toxic forms of oral tobacco create an enormous disease burden. ${ }^{2}$ The public likely does not fully appreciate the importance of tobacco in disease and death, especially now, given our collective 2 -year struggle to extricate ourselves from COVID-19, the worst infectious disease pandemic in a century. In the USA alone, COVID-19 has claimed the lives of nearly 1 of every 400 citizens. As such, it is especially sobering to recognise that cigarette smoking has killed even more Americans during the same period. And unlike COVID-19, smoking exacts its horrific toll year after year after year, not once in a century.

The story of modern tobacco control dates back 60 years to the release of two seminal publications: the smoking and health reports of the UK Royal College of Physicians in $1962^{3}$ and the US Surgeon General's Advisory Committee in $1964 .{ }^{4}$ At the time, a majority of men in many countries smoked, and smoking was rising rapidly among women. Smoking was a normative social behaviour. The opposite is true today, especially in the world's developed countries. In the USA, for example, at the dawning of the tobacco control era, nearly one of every two adults was a smoker. Today, that figure has decreased to 1 in 7 . Through cigarette taxation, smoke-free laws, marketing restrictions, package warning labels, media antismoking campaigns and smoking cessation treatment, tobacco control has saved the lives of many millions of people around the globe. ${ }^{5}$

But...

Global cigarette consumption rose annually for more than a century. A hundred years ago, in 1920, global cigarette consumption totalled 300 billion cigarettes. In 2009, the global total peaked at 5.9 trillion cigarettes, a 20 -fold increase. Global consumption began to fall just over a decade ago. ${ }^{6}$ Today, cigarette smoking kills approximately 8 million people worldwide each year, ${ }^{1}$ accounting for an astonishing 14\% of deaths from all causes.? Furthermore, smoking's disease and death toll is distributed unevenly across and within societies. A large and growing majority of the deaths occur in the world's low- and middle-income countries. ${ }^{8}$ In affluent societies, smoking is concentrated in marginalised populations-people suffering from mental health problems, individuals with low education and limited economic means, some minority groups, especially indigenous peoples, and members of the LGBTQ community. Dramatically reducing smoking is a matter of social justice. ${ }^{9}$

Is it too much to imagine that we can do that, and do it in the near future? With cigarette smoking prevalence hovering around $13 \%-14 \%$ in several affluent countries, the goal of achieving the proverbial 'smoke-free society' in those countries in the next decade or so seems feasible ${ }^{10}$ if we define the smoke-free society as one in which smoking prevalence has declined to no more than $5 \%$, a common goal of the handful of countries that have stated their intention to pursue a tobacco 'endgame'. ${ }^{11}$

Those pledges have been hollow words, until now. The government in Wellington, the capital of New Zealand, has made that country the first to put words into action, having developed an ambitious plan to rid their country's population of the scourge of smoking once and for all. The plan includes decreasing the allowable level of nicotine in cigarettes to non-addictive levels, raising the price of cigarettes persistently and substantially, limiting the number of cigarette sales outlets, enhancing the availability of smoking cessation services, supporting the use of vaping products as alternatives to smoking and permanently prohibiting the sale of tobacco products to anyone born after 2008 (the 'smoke-free generation' policy). ${ }^{12}$ 
The Kiwis' plan seems audacious, to say the least. Some may call it foolish, even impossible to fully implement. Before dismissing it, however, we should recall similar reactions when, in 2004, Ireland banned smoking in all workplaces, including restaurants and bars. Ridiculous, said the naysayers. It will go nowhere. History has proven that prediction wrong.

The road ahead for tobacco control will be bumpy, as it always has been. But it will inexorably move in the direction of dramatic diminution of the presence and toll of smoking. Tobacco Control will be there to document the progress, and likely to hasten it, as it has for the past three decades. Over the next few years, the Kiwis' progress will undoubtedly be recorded and analysed in the pages of the journal, especially given that the journal's current editor, Ruth Malone, is herself a leading figure in the effort to promote national tobacco endgames. ${ }^{11} 13$

Happy 30th, Tobacco Control. It has been an educational pleasure for all of us to watch you grow from infancy to a stellar maturity. My optimistic anniversary wish for us all: 30 years from now, there will no longer be a need for a journal devoted to tobacco control.

\section{Contributors KEW conceived and wrote this paper.}

Funding The author has not declared a specific grant for this research from any funding agency in the public, commercial or not-for-profit sectors.

Competing interests None declared.

Patient consent for publication Not required.

Ethics approval This study does not involve human participants.

Provenance and peer review Commissioned; internally peer reviewed.
ORCID iD

Kenneth E Warner http://orcid.org/0000-0002-8214-1776

\section{REFERENCES}

1 The Lancet. The global burden of tobacco. Available: https://www.thelancet.com/ infographics/tobacco [Accessed 19 Dec 2021].

2 Siddiqi K, Shah S, Abbas SM, et al. Global burden of disease due to smokeless tobacco consumption in adults: analysis of data from 113 countries. BMC Med 2015;13:194.

3 Royal College of physicians. Smoking and health. A report of the Royal College of physicians on smoking in relation to cancer of the lung and other diseases. London: Pitman medical publishing company, LTD, 1962.

4 U.S Dept. of Health, Education, and Welfare. Smoking and health. Report of the Advisory Committee to the surgeon General of the Public Health Service. Public Health Service publication No. 1103. Washington: U.S: Government Printing Office, 1964.

5 Holford TR, Meza R, Warner KE, et al. Tobacco control and the reduction in smokingrelated premature deaths in the United States, 1964-2012. JAMA 2014;311:164-71.

6 Elflein J. World consumption of cigarettes 1880-2017. Statista, 2021. Available: https://www.statista.com/statistics/279577/global-consumption-of-cigarettes-since1880/\#statisticContainer [Accessed 16 Dec 2021].

7 Our world in data. Number of deaths per year, world.. Available: https:// ourworldindata.org/grapher/number-of-deaths-per-year [Accessed 16 Dec 2021].

8 World Health Organization. Tobacco, 2021. Available: https://www.who.int/newsroom/fact-sheets/detail/tobacco [Accessed 16 Dec 2021].

9 Balfour DJK, Benowitz NL, Colby SM, et al. Balancing consideration of the risks and benefits of e-cigarettes. Am J Public Health 2021;111:1661-72.

10 Working paper, Dept of Health Management and Policy, University of Michigan School of Public Health, Ann Arbor, MI, 2021.

11 Malone RE. The race to a tobacco endgame. Tob Control 2016;25:607-8.

12 Ministry of Health, New Zealand. Smokefree Aotearoa 2025 action plan, 2021. Available: https://www.health.govt.nz/system/files/documents/publications/ hp7801_-_smoke_free_action_plan_v15_web.pdf [Accessed 16 Dec 2021].

13 McDaniel PA, Smith EA, Malone RE. The tobacco endgame: a qualitative review and synthesis. Tob Control 2016;25:594-604. 